DOI: 10.21625/resourceedings.v2i3.630

\title{
Materiality and Immateriality of Neglected Historical Churches: Preservation and Adaptive Reuse
}

\author{
Marina D'Aprile ${ }^{1}$

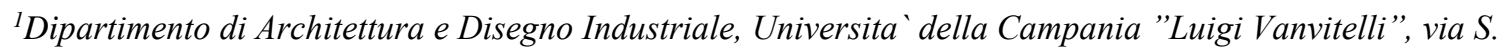 \\ Lorenzo, Aversa, 81031, Caserta, ITALY, Italia.
}

Email: marina.daprile@unicampania.it

\begin{abstract}
One of the more controversial topics about the preservation of disused historic buildings regards how to ensure them a sustainable future. This question is especially problematic respecting the increasing stock of worship places, like churches, fallen into disuse, closed or abandoned. The recognition and the safeguard of tangible and intangible values associated with them raise many debates on how these buildings should be protected and handed down to the future, complying with the community's current needs concurrently. Should there be limits on reusing former worship places? Given the changing meaning of sacredness over time, how should 'sacred values' of disused church buildings be recognized and maintained? Can they be preserved adapting churches for new purposes? What about the building's atmosphere? Should it be retained? Should it be adapted to the building's new use?

These and other questions, even involving the socioeconomic sphere, notably mark the field, given that the number of disused historic and modern Christian church buildings is still increasing throughout the West. Gathering different orientations and practices ranging from the historic preservation up to the building refurbishment, the so-called 'adaptive reuse' of buildings has been becoming more and more often habitual within Western countries even for disused worship places. Conversions of former churches according to this trend are differently valuable from a preserving perspective, since they have often implied remarkable changes to the building's identity and integrity, even compromising the recognition and the safeguard of intangible values associated with. How should new uses be chosen, so that they do not endanger tangible and immaterial attributes of church buildings? Is the adaptive reuse the most suitable strategy in order to approach all the cited issues?

Providing a brief overview on what the adaptive reuse of Christian church buildings fallen into disuse methodologically consists of, the study aims to suggest some answers to the mentioned questions, resorting to last specific international recommendations and guidelines. The prime limits and implications of the adaptive reuse of these buildings have been thus profiled regarding the preservation of tangible and intangible values they involve, concluding that only values centered preserving approach can provide a valid framework to face the challenge of the increasing redundancy of worship places.
\end{abstract}

(C) 2019 The Authors. Published by IEREK press. This is an open access article under the CC BY license (https://creativecommons.org/licenses/by/4.0/).

\section{Keywords}

Reversibility; Compatibility; Spirit of Place; Restoration; Atmospherological Aesthetics. 


\section{Introduction}

The decades-long, far-reaching decline of traditional worships encompassing the Christian West and the Protestants above all, the growing urbanization and the secularism along with social, demographic and economic changes have been producing an increasing redundancy of sacred buildings. The secularization is both an effect and a cause within this scenario, determining shrinking congregations and declining financial support. However, the "secularization paradigm" may not be irreversible (Bruce, 2006) due to the secularization, de-secularization and "re-sacralization" patterns (Backstrom, 2004) have been continually marking our time (Rosati, 2002), molding it as a "post-secular" society (Rusconi, 2008). Nonetheless, many controversial questions raise today on how to face the increasing redundancy of worship places (Coomans et al., 2012; Fiorani et al., 2017). Should sacred values be maintained in the face of decreasing interest in religion? How do the values associated with churches affect the re-use of church buildings? What purpose is their reuse for? May a church building ever be anything other than a church? How should the re-use process be undertaken and what form of sponsorship with?

Many Europeans and North American countries have been turning to the so-called 'adaptive reuse' as a common standard for the treatment of the increasing number of disused church buildings. First formulated in the 1970s, "challenged and propelled by economic, ecologic, socio-cultural and politic concerns", this approach enables diverse operational building practices - i.e., preservation, restoration, remodeling, recycling, renovation, rehabilitation and refurbishment (Plevoets and Van Cleempoel, 2013). Mainly coming from English-speaking countries and Central Europe many scholars have been advocating this trend as a balanced approach in order to integrate the building's preservation and renovation (Robert, 1991; Stovel et al., 2005 Plevoets and Van Cleempoel, 2013; Rogers 2013). The Netherlands, North America and Western Europe are the most experienced countries in the field. Many historic church buildings have been there converting into commercial, residential and office venues - usually the more controversial uses - while others have been adapting for entertainment and cultural services or for mixed and shared uses. The reuse potential of a church is affected by the building's fabric, defining features and structural condition, by all the stakeholders involved, the process used and the regulatory context, as well as by finance and site issues. Despite the variability and multiplicity of these factors, should there be overall limits for former churches' new uses? Should the transformation of the building's layout and spatial arrangement be considered as a proper choice, provided that it is carried out reversibly, clearly differentiating new additions and treatments from the old?

Churches are historically designed to go beyond utility reaching towards symbolic higher forms. Spiritual and symbolic meanings are retained even if church buildings fallen in disuse or are abandoned. The more intrusive adaptive reuses instead treat the fabric as a more or less awe-inspiring 'envelope', impairing the building's identity and integrity. May the adaptive reuse be a successful strategy in order to preserve both the building's physical integrity - i.e., the multi-layered substance of buildings, consisting of any change and addition they underwent over time and the symbolic values involved, at the same time providing a sustainable future to a former church? What are churches' intangible qualities and how should they be recognized and preserved?

Many scholars have been studying methodological, operational and juridical factors affecting the re-use of former worship places. They have highlighted that the compatibility of new functions with the building's preservation is one of the more critical issues in order to respect cultural expressions, economic feasibility and social involving at once (Stovel et al., 2005; Coomans et al., 2012; Fiorani et al., 2017). Briefly delineating what today's adaptive reuse of church buildings methodologically consists of, the study points out the prime limits this approach entails respecting the historic preservation criteria. The main criticism to historic churches' conversions inspired by this trend has usually come from preservationists in addition to the believers, of course. Referencing to last international recommendations and guidelines addressing the field, the research paper aimed at suggesting some answers to the cited issues, highlighting the strategic roleplayed by an appropriate methodological framework strictly based on values-centered preserving approach. 


\section{Material and immaterial values of church buildings}

The intangible values embedded in objects are the key to understanding their meaning. People invest things and places with differentiated meanings, most of which associated with memory. On the other hand, memory appeals to a shared public level and to the personal level, thus giving form to what is usually called as "the spirit of place" (ICOMOS, 2008). Public perception is then a foundational source in recognizing and interpreting the cultural and aesthetic values of architecture. Ritual, gestural and narrative traditions, symbols, events, beliefs, lore and memories have over time made church buildings landmarks to the community and the personal narratives of many.

For decades now the preservation of immaterial cultural heritage has been increasingly getting promoted. Since Burra's Charter (1979), the Nara Document (1994) and 2003's UNESCO Conference in Paris (Convention, 2003), this increasing prominence has sometimes ended up getting conflicted with the safeguard of tangible cultural heritage (Fiorani, 2014; Bortolotto, 2014). In other words, today's historic preservation architectural practice seems to have aroused the interest in current usage of buildings from passing the fabrics on to the future. That makes the building's materialism somehow less substantial than the perception and relational dynamics developed by the users, sometimes ending up too much conditioning preserving practices. Along with the building's distinctive features immaterial references compound what the neo-phenomenological aesthetics (atmospherology) are used to call the atmosphere radiated from objects and places as sentimental and multi-modal affordance inviting us to experience feelings. Atmosphere is then something in-between, mediating between subjects and objects, a "quasi- thing" condensed and effused within a place, which people resonate with (Griffero, 2010). "We feel the 'tangible' in so far the atmosphere radiating from it enters our emotional state" (Böhme, 1995). Architects then shape "sentimental spaces", working on the user's perceptions with power of suggestion and manipulation (Griffero, 2014). Atmosphere is part and parcel of the building's identity; therefore, once we want to preserve a building also its atmosphere must be retained. But, are 'sacred atmospheres' actually preserved when we reuse church buildings whatever purpose for?

The "Secretary of the Interior's Standards for the Treatment of Historic Properties" - the main document of reference for historic preservation practice in the United States - list the rehabilitation, usually referred to as adaptive reuse, as "the process of returning a property to a state of utility, through repair or alteration, which makes possible an efficient contemporary use, while preserving those portions and features of the property which are significant to its historic, architectural, and cultural values" (National Park Service, 1992). In order to minimize changes to buildings "compatible uses" are here also advocated. This compatibility is but limited to the building's physical substance regardless of reuse purposes. As also these words evidence, the adaptive reuse then prioritizes the need of returning historic buildings to a state of efficiency and usefulness over any other value, being factually led by functional needs. Consequently, it lacks the extensive documentation, investigation and recording of the building's nature, condition and historic development, that are instead the key to historic preservation practice. Many adaptive reuses of church buildings therefore entailed new interior arrangements, which induce "a sort of semantic detachment that aspires to neutralize the symbolic focus" of the church, thus ignoring and changing 'affordances' and emotional resonances it raised (Fiorani, 2017; Gibson, 1979). Nonetheless, we must consider that some theologies, typically the Protestant, are used to de-emphasize worship places, prioritizing the believers' needs rather than physical venues of their worship (Coomans et al., 2012).

The Kruisherenhotel housed in the Gothic church of the former Kruisheren monastery in Maastricht (Fig. 1-2) is a case in point in this regard. The new use has here prevailed upon the building's identity modifying its original layout and spatial arrangement, even if the works were carried out clearly differentiating the new from the old. Purposes like the commercial and residential usually aim at the maximization of space, thus clashing with the historic preservation criteria, which are instead intended to minimize changes to buildings. A thoughtful approach to the reuse of churches should avoid this conflict, providing for both the buildings' safeguard and sustainable use. New interior partitions blocking the view of the character-defining open space of churches drastically disrupt the feeling of numinosity that churches suggest, even if they are fulfilled with low walls or box-in-box structures. Partitioned apses and altar areas also impair the church's interior spatial values, being them the focal points of the church's layout. Nonetheless, many 
new additions introduced by the adaptive reuse of churches might be defined 'reversible' and clearly differentiated from the old, so evidencing how much more complex is to compatibly integrate the building's preservation and reuse.

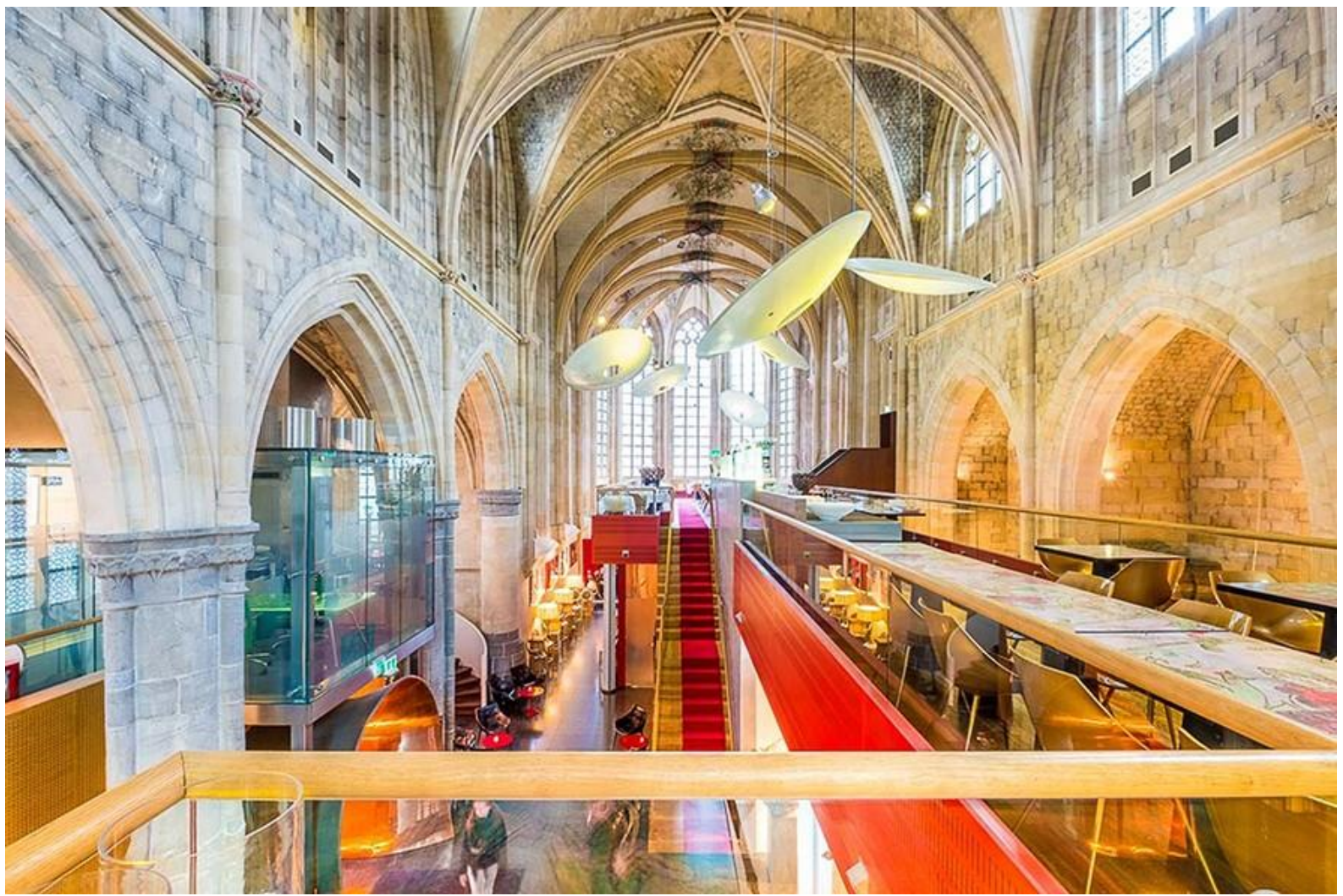

Figure 1. Maastricht. Kruisherenhotel. The Gothic church today (https://www.hungryformore-mag.com/en/travel/kruisherenh otelmaastricht/)

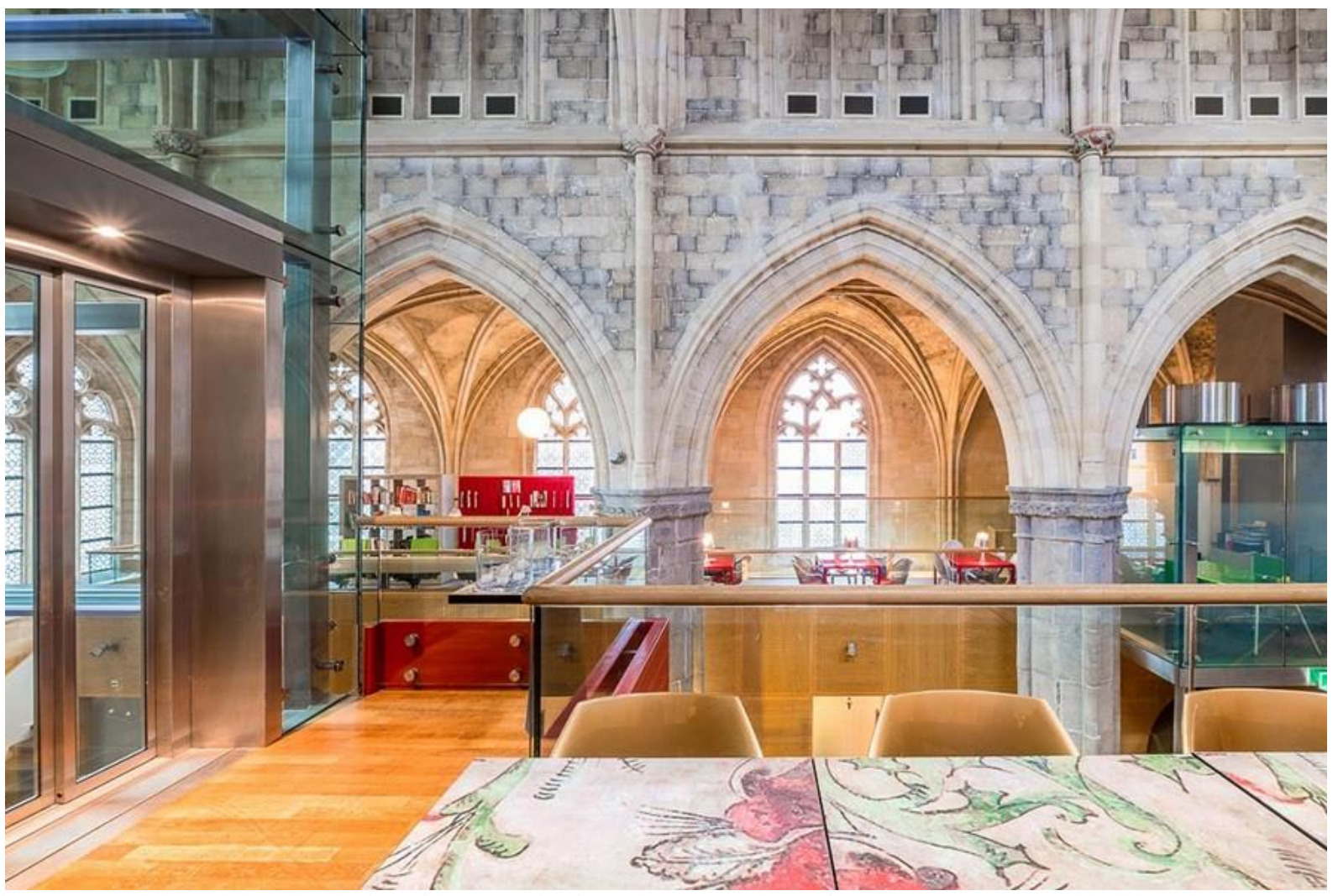

Figure 2. Maastricht. Kruisherenhotel. View of the mezzanine floor. (https://www.hungryformore-mag.com/en/travel/kruisherenhotelmaastricht/) 


\section{International criteria and guidelines for reusing sacred buildings}

The role of the Churches in addressing the fate of disused religious heritage is essential, even when they are not the owners of buildings to be reused anymore. Since the 1980s, many Churches have recognized the need to think about how to handle the buildings they cannot longer maintain. The Protestants and the Catholics usually take a very similar approach to the field, establishing diverse forms of organization, documents and guidelines in order to protect this sensitive heritage. For instance, amongst other initiatives, the Belgium-based international nongovernmental organization "Future of Religious Heritage" (FRH) has been founded in 2010 as a network initiated by amongst others English Heritage, the Churches Conservation Trust, the Church of Sweden and the Norwegian Directorate of Cultural Heritage. In Italy the Italian Central Pontifical Commission for Sacred Art approved the "Charter for the reuse of ancient ecclesiastic buildings" in 1987, explicitly declaring the need to adopt the historic preservation criteria such as they were issued by the late-20 $0^{\text {th }}$ century international charters (Carta, 1987). Just two years later, harking back to the cited 1987's Charter, also the Council of Europe's Parliamentary Assembly claimed that for former churches "future uses, whether religious or cultural" must be found "as far as possible compatible with the original intention", concurrently supporting the community's engagement within the whole decision process (Resolution 916, 1989). In order to face the growing debate raised on the redundancy of religious buildings and the market trend that increasingly has been converting churches into homes, in 2014 the Italian Ministry for Tourism and Cultural Resources and Activities issued the "Guidelines for the management and preservation of the religious heritage" (Linee guida, 2014). Later, the Pontifical Council for Culture and the episcopal conferences of Europe, Canada, the United States and Australia edited the "Guidelines for decommissioning and ecclesial reuse of churches", the very last international reference to the subject (Guidelines, 2018). Today's historic preservation criteria are here explicitly recalled as "the constitutive set of elements" in order to document, survey, understand and protect religious buildings to be reused, so that their identity and physical integrity can be retained. In particular, the Guidelines underline that the only proper means to deal with the reuse of former churches stands on the building's extensive documentation and record, so that any new use can be compatibly verified with the building's preservation. For historic preservation this process is indeed based on a precise methodological framework, which aims at recognizing and interpreting the building's tangible and intangible nature, historic development and current vulnerability.

The type of new uses promoted by the Guidelines is somewhat limited, even regardless to what extent it requires changes to the building's fabric. In particular, new uses cannot, or rather should not, contradict the original use as a church and the values represented by the Church, preferring those that are related to church activities or that harmonize with church values, like cultural and social ones (cultural centers, concert halls, museums, art galleries, schools, kindergartens, charitable facilities, etc.). Event, sport and gym halls, even when non-compromising original spatial arrangements, are considered as impeding the preservation of the building usually, since they involve the dismantling of furniture and the resort to heavy plant installations. Musealisations that require intrusive plant installations (e.g. light, climate, safe-control systems, etc.) are then likewise seen as incompatible with the size and spirit of worship places, such as it is for major cultural concert halls and centers requiring intrusive changes of the church's spatial arrangement. While commercial conversions are not preferred at large, some uses like residential and office use having a social goal (e.g. public or subsidized housing) or promoting church values (e.g. offices for a religious publisher) are however advocated by the Church.

A case-by-case approach within an overall methodological frame is then what the Guidelines have stated, highlighting the need to develop a wide collaboration in the decision-making process with all the stakeholders involved (church officials, Municipalities, heritage and local associations, etc.), while adopting bottom-up dynamics in order to increase the social involvement and inclusiveness. Socio-cultural uses are considered as the best options to match the building preservation and the public usage, provided that conversion works, grounding on an overall understanding of the building's multi-layered nature, are respectful for the basic requirements of the historic preservation practice (i.e., minimal intervention and physical changes; respect for the building's authenticity; durability, compatibility, reversibility and clear distinction of treatments and new additions from the old; environmental, socio-cultural and economic sustainability of new treatments and uses). In particular, in order to identify compatible new uses the Guidelines state the need to cure at once "the concepts of resilience, sustainability, 
co- responsibility (re-appropriating by communities as an interpretative and forward-looking criterion to allow for resilient and sustainable transformation works) and planning (to develop a coordinating territorial visioning of the field, not looking at each single case separately" (Guidelines, 2018). Full commercial for-profit reuses are excluded, while the conversions into social enterprise or other Christian communities and worships venues, as well as for charitable usages are advocated, since they correspond to the Church's characteristics. Public multifunctional or shared reuses are also promoted. Only for church buildings with "lesser architectural values" the residential use may be allowed, but the Guidelines do not clarify what these "lesser" values should be like.

\section{Conclusions}

Cultural heritage entails multiple levels of tangible and intangible meanings changing over time, that we could never fully understand (Nora, 1989). More than other buildings, churches are wrapped in a complex set of values, so that controversial effects can arise when it comes to adapting them for new uses, due to the reuse depends on to how people interpret the links between the building and the sacredness. As established by the documents and guidelines mentioned above, any reuse of historic buildings is to be part and parcel of a comparative process, whose primary goal must be to maintain the building's identity and physical integrity along with any immaterial value associated with it. "The respect for cultural and heritage diversity requires conscious efforts to avoid imposing mechanistic formulae or standardized procedures in attempting to define or determine authenticity of particular monuments and sites" (Nara's Document, 1994, Annex 1). A case-by-case methodology rooted in a strictly preserving approach then stands out as a recommended strategy. As the cited Guidelines (2018) have stated, conversions of former worship places should accomplish new purposes respectful for the building's integrity and identity ensuring the fabric a sustainable future, only by accurately adopting values-centered preserving approach that, at the same time, allows a wider engagement of the community informing people about the proposed new use early on, so that they have the opportunity to voice their concerns. According to these goals, in the end collaborative strategies like public-private partnerships can be an extremely effective means in order to preserve and compatibly reuse historic church buildings.

\section{References}

Bäckström, A. (2004). Religion in the Nordic Countries: Between Private and Public. Journal of Contemporary Religion, 29(1), 61-74

Böhme, G. (1995). Atmosphäre. Essays zur neuen Ästhetik, Frankfurt a. M.: Suhr-kamp.

Bortolotto, C. (2014). La problemática del patrimonio cultural inmaterial. The problematic of intangible cultural heritage. Culturas. Revista de Gestión Cultural; 1(1): 1-22

Bruce, (2006). Bruce S. Secularization and the Impotence of Individualized Religion. The Hedgehog Review, Spring and summer. 35-45.

Carta, (1987). Central Pontifical Commission for Sacred Art in Italy. Carta sulla destinazione d'uso degli antichi edifici ecclesiastici / Charte sur l'utilisation des anciens bâtiments ecclésiastiques. Arte cristiana, 1987 ; 75: 410-412

UNESCO (2003). Convention pour la sauvegarde du patrimoine culturel immatériel, Paris, Unesco, $32 \mathrm{e}$ session, 29 septembre-17 octobre 2003. Retrieved from http://www.unesco.org/culture/ich/index.php?lg=fr\&pg=00022\#part1 [Accessed Jan. 2019]

Coomans, T., De Dijn, H., De Maeyer, J., Heynickx R. \& Verschaffel, B. (2012). Loci Sacri. Understanding Sacred Places. Leuven: Leuven UP.

Fiorani, D. (2014). Materiale/Immateriale: frontiere del restauro. Materiali e strutture. Problemi di conservazione, 3, V-VI: 9-24

Fiorani, D. (2017). Conservation and new uses in spaces of the holy. In: Fiorani et al., 117-130

Fiorani, D., Kealy, L. \& Musso, S.F. (2017). Conservation-Adaptation. Keeping alive the spirit of the place. Adaptive reuse of heritage with symbolic value. EAAE Transactions on Architectural Education no. 65. Hasselt (Belgium): Arti Grafiche.

Gibson, JJ. (1979). The ecological approach to visual perception, Boston: Houghton Mifflin.

Griffero, T. (2010). Atmosferologia. Estetica degli spazi emozionali, Roma-Bari: Laterza.

Griffero, T. (2014). Architectural affordances. The atmospheric authority of spaces. In Tidwell P. editor. Architecture and atmosphere. Helsinki: Tapio Wirkkala-Rut Bryk Foundation, 15-47.

Guidelines (2018). Pontificium Consilium de Cultura. Guidelines for decommissioning and ecclesial reuse of churches. Vatican, December 17 $7^{\text {th }}$, 2018. Retrieved from http://www.cultura.va/content/dam/cultura/docs/pdf/beniculturali/Guidelines_Decommission.pdf [Accessed March 2019].

ICOMOS (2008). ICOMOS. Québec Declaration on the Preservation of the Spirit of Place. Adopted at Québec, Canada, October $4^{\text {th }}, 2008$. Retrieved from http://www.icomos.org/quebec2008/quebec_declaration/pdf/GA16_Quebec_Declaration_Final_EN.pdf>[Accessed March 2019] 


\section{D’Aprile/ Proceedings of Science and Technology}

Linee guida (2014). Ministero dei beni e delle attività culturali e del turismo. CEI. Linee guida per la tutela dei beni culturali ecclesiastici, 2014. Retrieved from http://www.beniculturali.it/mibac/multimedia/MiBAC/documents/feed/pdf/Linee\%20Guida\%20Tutela\%20Beni\%20 Culturali\%20Ecclesiastici-imported-48392.pdf [Accessed Jan. 2019]

National Park Service (1992). Technical Preservation Services. The Secretary of the Interior's Standards for Rehabilitation. Retrieved from https://www.nps.gov/tps/standards/rehabilitation/rehab/stand.htm [Accessed March 2019]

Nora, P. (1989). Between Memory and History: Les Lieux de Mémoire. Representations, 1989; 26. Special Issue, Memory and Counter-memory: 7-24

Plevoets, B. \& Van Cleempoel, K. (2013). Adaptive reuse as an emerging discipline: an historic survey. In: Cairns G, editor. Reinventing architecture and interiors: a socio-political view on building adaptation. London: Libri Publishers. p. 13-32

Resolution 916 (1989). Council of Europe. Parliamentary Assembly. Resolution 916. Redundant religious buildings. Retrieved from http://semanticpace.net/tools/pdf.aspx?doc=aHR0cDovL2Fzc2VtYmx5LmNvZS5pbnQvbncveG1sL1hSZWYvWDJILURXLWV4dHIuYX NwP2ZpbGVpZD0xNjMyNyZsYW5nPUVO\&xsl=aHR0cDovL3NlbWFudGljcGFjZS5uZXQvWHNsdC9QZGYvWFJ1Zi1XRC1BVC1YT UwyUERGLnhzbA==\&xsltparams=ZmlsZWlkPTE2MzI3 [Accessed Jan. 2019]

Robert, P. (1991). Adaptations. New Uses for Old Buildings. English translation by Murray W. New York, NY: Princeton Architectural Press.

Rogers, S.A. (2013). Religious Conversions: 15 Houses of Worship Turned Secular. Retrieved from http://weburbanist.com/2013/09/09/religiousconversions-15-houses-of-worship-turned-secular/ [Accessed Feb. 2019]

Rosati, M. (2002). Solidarietà e sacro: secolarizzazione e persistenza della religione nel discorso sociologico della modernità . Roma-Bari: Laterza.

Rusconi, G.E. (2008). Lo Stato secolarizzato nell'età post-secolare. Bologna: Il Mulino.

Scott, F. (2008). On Altering Architecture. London-New York: Routledge..

Stovel, H., Stanley-Price, N. \& Killickm R. (2005). Conservation of Living Religious Heritage. Papers from the ICCROM 2003 Forum on Living Religious Heritage: conserving the sacred. Rome: ICCROM; 2005. Retrieved from https://www.iccrom.org/sites/default/files/ ICCROM ICS03 ReligiousHeritage en.pdf [Accessed March 2019] 